\title{
VIII. Two Letter's from George Godwin, Esq. F.R.S. \& F.S.A. to Sir Henry Ellis, K.H., F.R.S., Secretary, on certain Marks discoverable on the Stones of various Buildings erected in the Middle Ages.
}

Read 16th December 1841, and February 2, 1843.

\section{LETTER I.}

DeAr Sir,

Авоuт three years ago my attention was first drawn to the fact, that the Stones both inside and outside numerous ancient buildings in England bore in many cases a peculiar mark or symbol, which was evidently the work of the original builders. It immediately occurred to me, that these Marks, if extensively examined and compared, might serve to aid in connecting, and perhaps discriminating, the various bands of operatives, who, under the protection of the Church, mystically united, spread themselves over Europe during the middle ages, and are known as the Free Masons.

It therefore gave me some pleasure during a recent visit to the interior of France, to observe in several instances at Poitiers, in the department of Vienne, similar marks in great profusion; the more so too, as amongst them were many exactly resembling some which I had previously found in England, although on buildings of a different date.

Some of these marks, both from English and French buildings, are represented by the accompanying diagrams (Plates VI. VII. VIII. IX. X.). They are formed by a single line slightly indented, and vary in length from two to seven inches.

Nos. 1 to 7, (Plate VI.) are from the north aisle of the nave of Gloucester VOL. $\mathrm{x} \times \mathrm{X}$. 
114 Masons' Marks observable on Buildings of the Middle Ages.

cathedral, the walls of which have been thickly covered with them. Nos. 8, 9,10 , and 11, are from the outside of the south transept of the same building. Nos. 12, 13, and 14, are from the cathedral at Bristol ; and 15, 16, 17, and 18, from the beautiful parish church of St. Mary Redcliff, in the same city.

Nos. 19, 20, 21, 22, 23, and 24, are from the south porch of the abbey church at Malmesbury (one of the most curious and interesting porches in England). The form No. 20 is similar to No. 11, from Gloucester cathedral. No. 21 is similar to No. 14, from Bristol cathedral ; though the buildings are of very different dates. No. 19, an interesting symbol, formed by an endless line, is fire or six inches in height, and occurs in numberless instances both here and elsewhere. Nos. 25 and 26 are from the tower of the church at Cirencester : and Nos. 27 to 66 inclusive, (Plate VII.) from Furness abbey, Lancashire. This latter building displaying the architecture of various periods, a few of the signs from each portion of the structure are given under their respective heads. The form, No. 19, at Malmesbury, already spoken of, occurs both in the semi-Norman, or transition work, at Furness, No. 34, and on an early-English capital, No. 46. No. 22 at Malmesbury also occurs here, see No. 54 .

The signs found on the perpendicular work, Nos. 61 to 66 , display a coincidence in the lines which is curious.

Nos. 67 to 76, (Plate VIII.) are taken from Cheetham's college at Manchester, and are seen to be similar in several instances to others already given.

Turning now to the buildings in Poitiers,-the cathedral of St. Pierre and church of St. Radégonde are literally covered with marks, the interior of the latter especially. Some of them are represented by Nos. 77 to 106, (Plates IX. and X.) and will be found similar to others in England. For example, Nos. 88 and 101 resemble No. 72, from Cheetham's college, Manchester, a building of much later date. No. 93 at St. Pierre is identical with 71 , from Manchester. No. 92 resembles No. 29, from Furness abbey; and in Nos. 98 and 103 we have the fish form, or Vesica Piscis, already seen in No. 18, from St. Mary's Redcliff, at Bristol. This, as is well known, was an early and much used symbol in the Christian church.

Whether these marks were made for the simple purpose of identifying the 
work done by particular individuals or subdivisions of the band, or that they had a deeper signification and motive, I will not now inquire: nor even venture to remark on the origin of the signs themselves per se. My present purpose is simply to draw attention to these marks, in the hope that collections may be made in England, France, and Germany, so that they may be properly investigated and compared. No circumstance which promises to throw even the smallest additional light on the early history of those wonderful men to whom we are indebted for. so many magnificent buildings, can be deemed insignificant or unworthy of consideration.

I have the honour to subscribe myself,

Dear Sir,
Your faithful Servant,
SIR HENRY ELLIS, K.H., F.R.S.
Sec. S.A.

LETTER II.

Dear Sir,

In the month of December, 1841, I had the pleasure of laying before the Society some observations on the fact, that the stones both inside and outside numerous ancient buildings in England and France, bear in many cases peculiar marks or symbols, apparently the work of the original builders. Since then I have had an opportunity of examining the Cathedral of Cologne, and some other sacred edifices in that city, where I found many similar marks. Copies of some of these, half real size, I beg leave to forward with this letter, (Figures 107 to 155, Plates IX. and X.) in order that they may be compared with the diagrams previously sent. 
In length they vary from $1 \frac{1}{2}$ inch to 2 inches. They are not so deeply cut in as those already spoken of, nor are they formed by so wide a line, but nevertheless they are all remarkably clear and distinct. More order is perceptible in the position of the marks in the interior of this cathedral than I have elsewhere observed; for example, they appear with considerable regularity up the centre of the four chief members of each of the great clusters of columns dividing the nave and aisles; and they commence at a certain height from the ground, nearly uniformly.

Monsieur Didron of Paris, it seems, has communicated a series of observations on these marks to the Comité Historique des Arts et Monuments. He has found them at Strasburgh, Spire, Worms, Rheims, Basle, and elsewhere, and believes he can discover in them reference to distinct schools, or lodges of masons. The marks collected by M. Didron divide themselves, according to his opinion, into two classes, those of the overseers and those of the men who worked the stones. The marks of the first class consist generally of monogrammatic characters, and are placed separately on the stones: those of the second class partake more of the nature of symbols, such as shoes, trowels, mallets, \&c. It is stated that at Rheims, in one of the portals, the lowest of the stones forming one of the arcades is marked with a kind of monogrammatic character, and the outline of the sole of a shoe. The stone above it has the same character, and two soles of shoes; the third the same character, and three soles, and so all round the arcade. The shoe mark he found also at Strasburgh, and no where else, and accounts for this by the fact, that parts of the cathedral of Rheims were executed by masons fetched from Strasburgh.

The Committee either have published, or are about to publish, a set of instructions to their correspondents on this point, with plates of the marks already collected, in order that they may obtain additional information, and means of comparison.

Strengthened by this proceeding on their part in my belief before expressed, that the observation and collation of these marks may ultimately aid in elucidating the history of the Free Masons, I feel encouraged to bring the subject again before the Society, which otherwise I should not have done. 
The lamented Mr. Rokewode, in a paper on the dedication and consecration of churches, printed in the 25th volume of the Archæologia, observes that "the ancient altar stone, known by the crosses graven in the centre and at the angles, is now frequently to be found in our churches, generally applied to sepulchral purposes. The crosses upon it were intended to mark the spots annointed with chrism, - and if I do not mistake, this was the object of the crosses once inlaid with metal, cut in the external walls of some churches, as in the cathedral of Salisbury, and the churches of Edindon in Wilts, Cannington in Somersetshire, and Brent Pelham in Herts. It may also be observed, that on one of the Norman pillars in New Shoreham church, are two Jerusalem crosses, probably graven on the occasion of the dedication."

Mr. Sydney Smirke in a paper which follows the last quoted, and illustrates it from the church of St. John at Syracuse, refers to a pontifical, printed at Rome in 1595, and now in the British Museum, where the Bishop is enjoined to mark with his thumb dipped in the chrism, twelve crosses on the walls of the church and others on the door, and altar. It further provides that these crosses are to be at the height of 7 feet 5 inches above the floor.

I do not quote these observations with the view of shewing an immediate connection between any religious ceremonies and the marks in question. They may however be deemed to bear, although slightly, upon the subject; and therefore they are introduced; the more so too, perhaps, because in searching for marks at Furness abbey, (where they abound,) a large cross 14 inches high, and 14 inches wide, was found, cut on the external face of a stone at the east end of the church. This is represented by fig. 158, Plate X.

The marks of which we are especially speaking, it can perhaps hardly be doubted, were made chiefly to distinguish the work of different individuals. At the present time the man who works a stone, (being different from the man who sets it,) makes his mark on the bed or other internal face of it, so that it may be identified. The fact, however, that in the ancient buildings it is only a certain number of the stones which bear symbols, - that the marks found in different countries, (although the variety is great,) are in many cases identical, and in all have a singular accordance in character, 
- seems to shew that the men who employed them did so by system, and that the system, if not the same in England, Germany, and France, was closely analogous in one country to that of the others.

Moreover, many of the signs are evidently religious and symbolical, and agree fully with our notions of the body of men known as the Free Masons.

With reference to the religious character of associated masons in very early times, (times much earlier than any of the works already mentioned belong to,) I am induced to allude to a curious MS. account of the proceedings of four sculptors who worked "in the name of the Lord." a It is in No. 91 of the Arundel MSS. at the British Museum, described as "Sanc. torum vite, miracula, et martyria," and is to be found at folio 218 , headed, "Claudii Sociorumq. ejus." It commences thus: "At the time when Diocletian was Emperor, various metallic substances were cut by the Pannonians from the mountains in his presence. It came to pass that when he had collected together all the workers in metal, he found amongst those endowed with great skill in art certain men named Claudius, Castor, Simphorianus, and Nicostratus, who were wonderful in the art of masonry. These men were secretly Christians, observing the commandments of the Lord, and, whatsoever work in the art of sculpture they performed, they did it in the name of Our Lord Jesus Christ."

Further on, it proceeds : "At the command of Diocletian, a porphyritic shell with pomegranates and foliage, was perfected by the hands of Claudius, Simphorianus, Castor, and Nicostratus, and they were brought under the notice of the Emperor. And he was pleased with all things, and made them many presents. Then said Diocletian, I desire that some columns with foliated capitals should be carved out of the porphyritic mountain under the direction of Claudius, Simphorianus, and Castor. When the philosophers heard this they were vehemently indignant because the command of Diocletian provoked them. Coming, however, to the mountain, they marked out the portion of stone which should be cut away. Then the artificers in masonry prayed, and made the sign of the cross of Christ, and giving directions and setting to work, they began to cut the stone for the neck of the columns, and they worked at it daily for three months. When, however, one

a My attention was kindly directed to this by Dr. Bromet. 
wonderful column had been produced with perfect art, the philosophers said to Claudius and the others, Ye who are enriched with gifts, give your skill to the shaping of another column. Wherefore, replied they, do ye wish to learn the art from us? Still, in the name of Our Lord Jesus Christ, in whom we trust, we will shape this other column like the first. And giving their labour with the utmost diligence, within twenty-six days they had cut the other column. Then the philosophers indignantly exclaimed, These mysterious words can only pertain to art-magical."

To return, however, to one or two additional items of information, respecting Masons' marks. Mr. John Gough Nichols has favoured me with tracings of two marks which appear upon the top edge of two Roman altars found at Risingham in Northumberland. They are represented by figures 156 and 157 , in Plate $\mathrm{X}$.

In a work by Messrs. Waller, on Monumental Brasses, recently published, ${ }^{\mathrm{b}}$ a circumstance is pointed out in connection with a monument to Sir John de Creke and Lady Alyne his wife at Westley Waterless, Cambridgeshire, (dated about 1325,) which bears strongly on the subject before us. The passage is as follows:-

"At the right foot of the lady's figure is a monogram, pro-

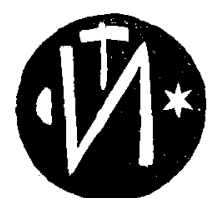
bably of the artist by whom it was executed; it is given the full size in the margin, and consists of the letter $\mathrm{N}$, above which is a mallet, on one side a half moon, and on the other a star or sun. It is worthy of remark, that the same device is found on a seal attached to a deed $5^{\circ}$ Edw. I., ${ }^{c}$ wherein one Walter Dixi 'Cementarius de Bernewelle' is conveying certain lands to his son Lawrence. The seal of Walter has for its legend S'. WALTER : LE : MASVN, and is likewise annexed.

"The occurrence of a similar device in two instances seems to show that it was not an individual mark. May it not have been the badge of some guild of masons? If so, it will suggest that the same minds that designed the archi-

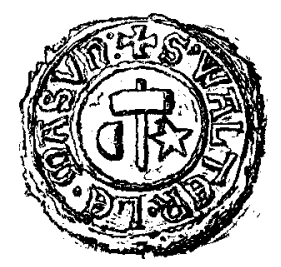

b " A Series of Monumental Brasses from the Thirteenth to the Sixteenth Century," by J. G. and L. A. B. Waller.

c Cole's MSS. vol. VIII. 
tectural structures of the middle ages also designed the sepulchral monuments; and this opinion is strengthened by the fact of their generally agreeing with the prevailing taste of the times."

Again,-in Lord Lindsay's work on Egypt, Edom, \&c. (vol. II. p. 361,) a description of a monument on the Orontes, and near Baalbec, is given in a note by a friend, and the following statement is made. "It is very remarkable, that the faces of this monument are covered with small marks, cut on the stones; hieroglyphics I cannot call them,- they are too numerous to be accidental, and I was convinced that they were not from the mere process of chiselling the stones." Whether or not they were analogous to the marks under consideration, I do not pretend to say.

In concluding these disjointed and perhaps trifling observations, I cannot avoid referring to what may be considered a curious coincidence. In June 1842, Mr. Hudson Gurney exhibited several tablets, described as having been discovered at the Nécropole de Hanschir Makther Weled Aijar, and which were covered with marks (almost like pattern cards) about the same size, and formed in the same way as those I had seen on the walls of many buildings. Some few of them being identically the same, I sketched hastily at the time, and now forward with this letter. See Figs. 1, 2, and 3, in Plate III. of the present Volume.

I have the honour to subscribe myself, dear Sir,

Your faithful Servant,

Sir Henry Ertis, K.H. F.R.S.

GEORGE GODWIN, JUN.

Sec. Soc. Antiq. 
E. NGLA N D .

(YOOCESTER IATHEDRAL, INSIIE NAVE.
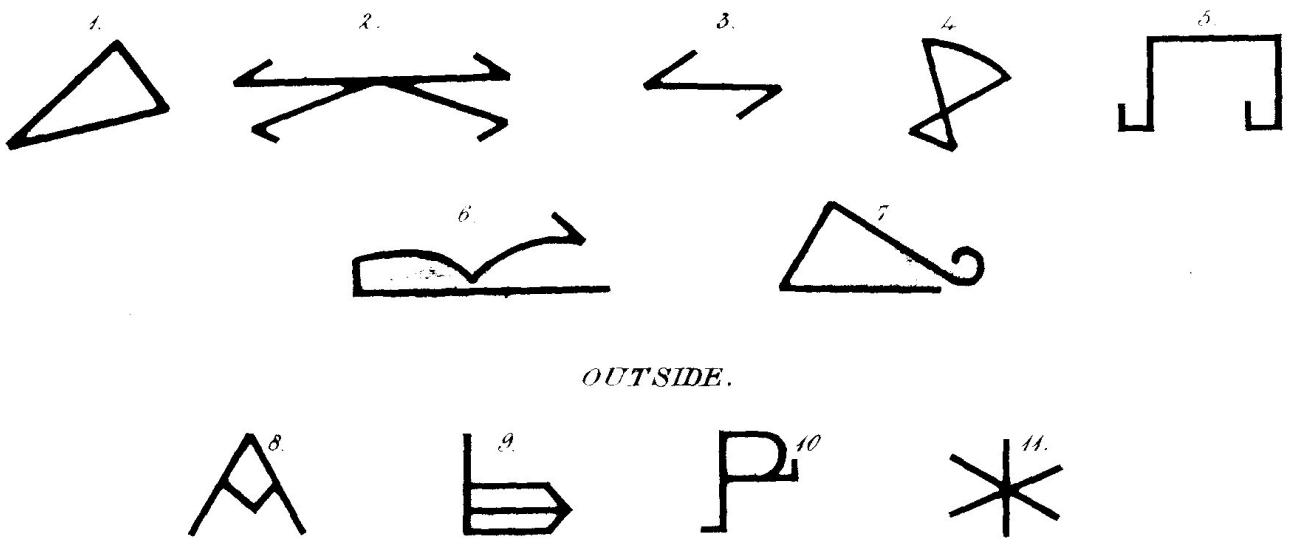

BRISTUL CATHEDRAL.
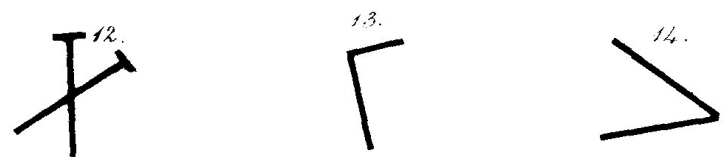

ST MARYS REDCLIFF.
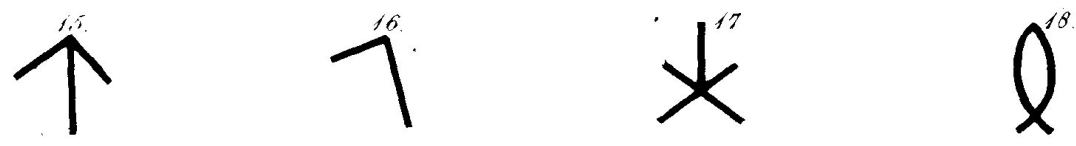

\section{MALMSELRY ABBEY CAURCH.}
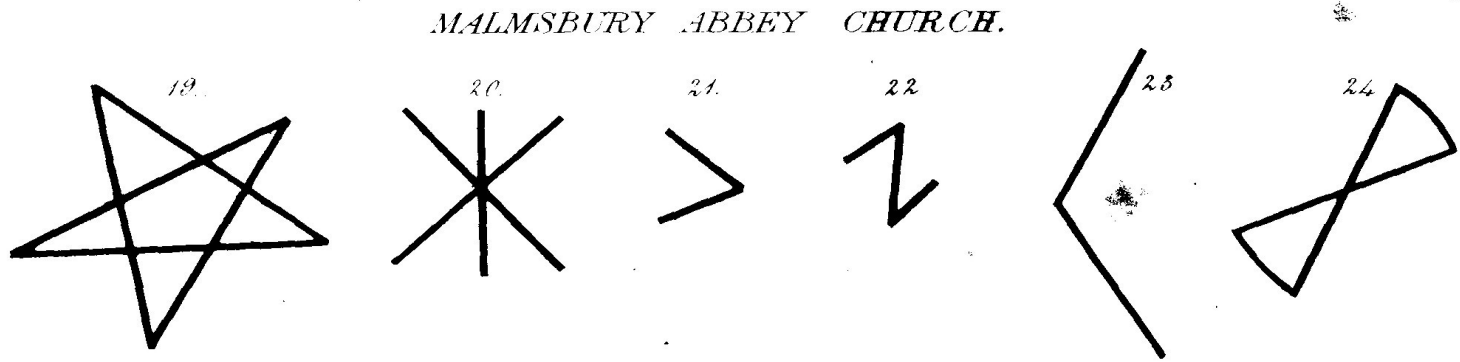

CHCRCH AT CIRENCESTER.
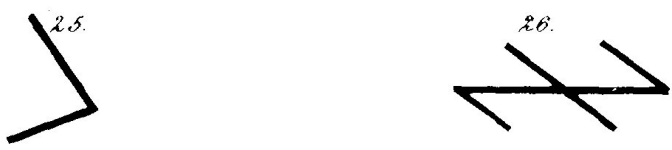

One fourth rea? size

Mason is Marks. 
FURNESS ABBEY.

TRANSTTTON PERTOD.
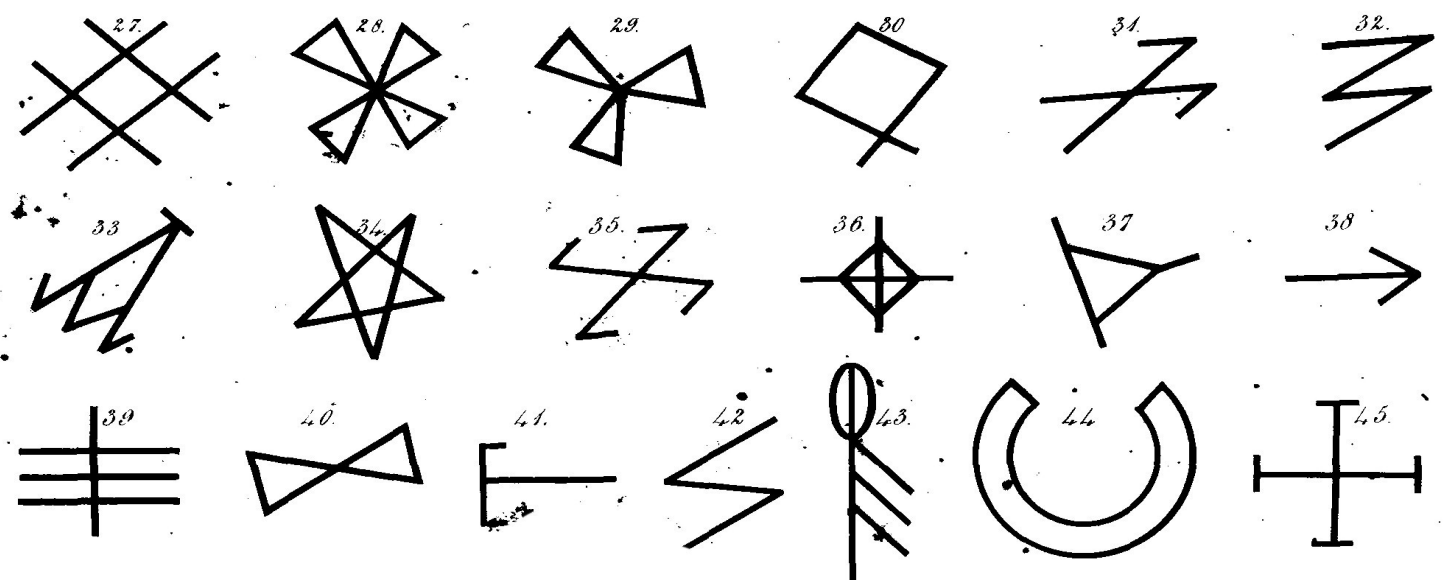

EARLY ENGLISH.

$2 x^{46}$
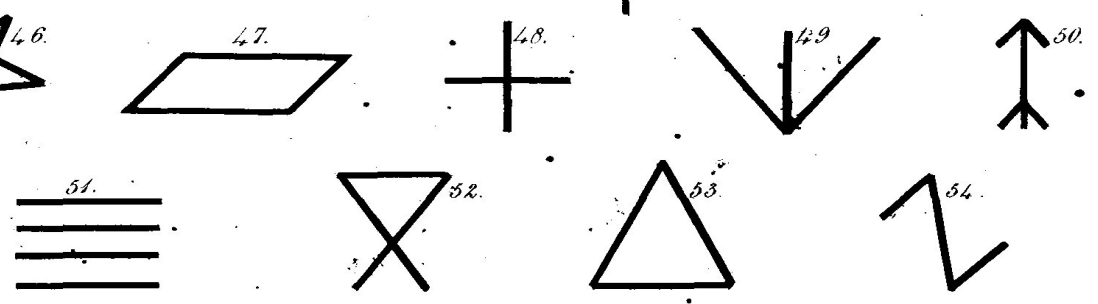

DECORATED AND PERPENDICUTAR PERIODS.
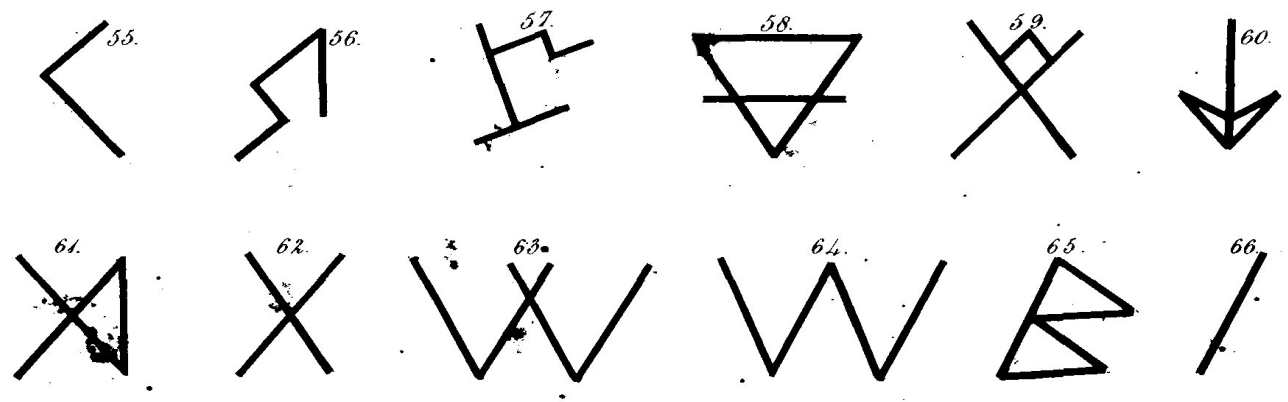

One fourth real sire.

Mason's Marks. 


$$
\text { E NGLAND. }
$$

CHEETHAMS COLLECE MAVCHESTER.

$P^{6 \pi}$
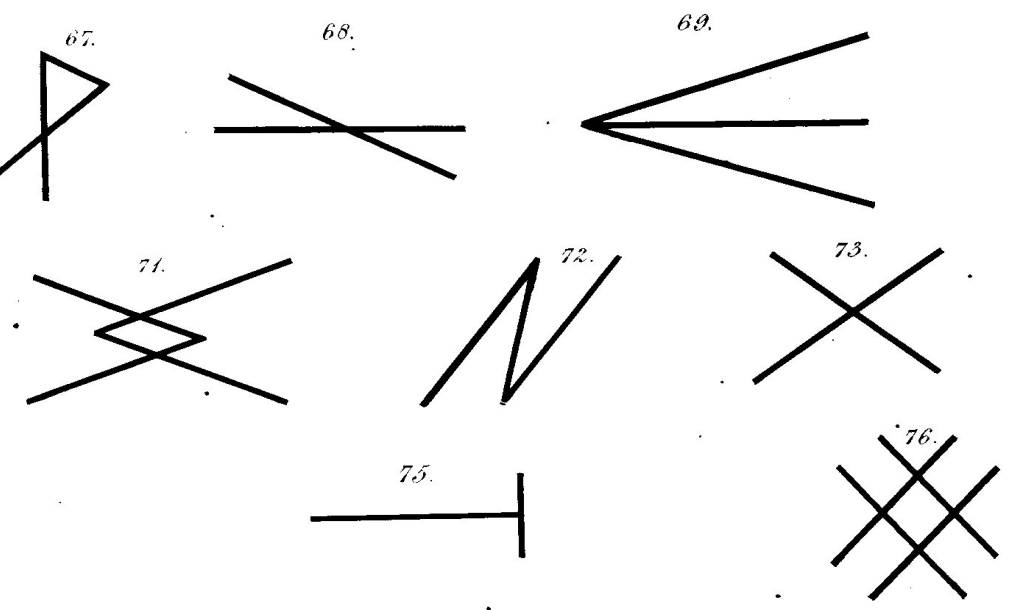

POITIERS. FRANCE.

ST PIERLE,. OIT'SIDE'.
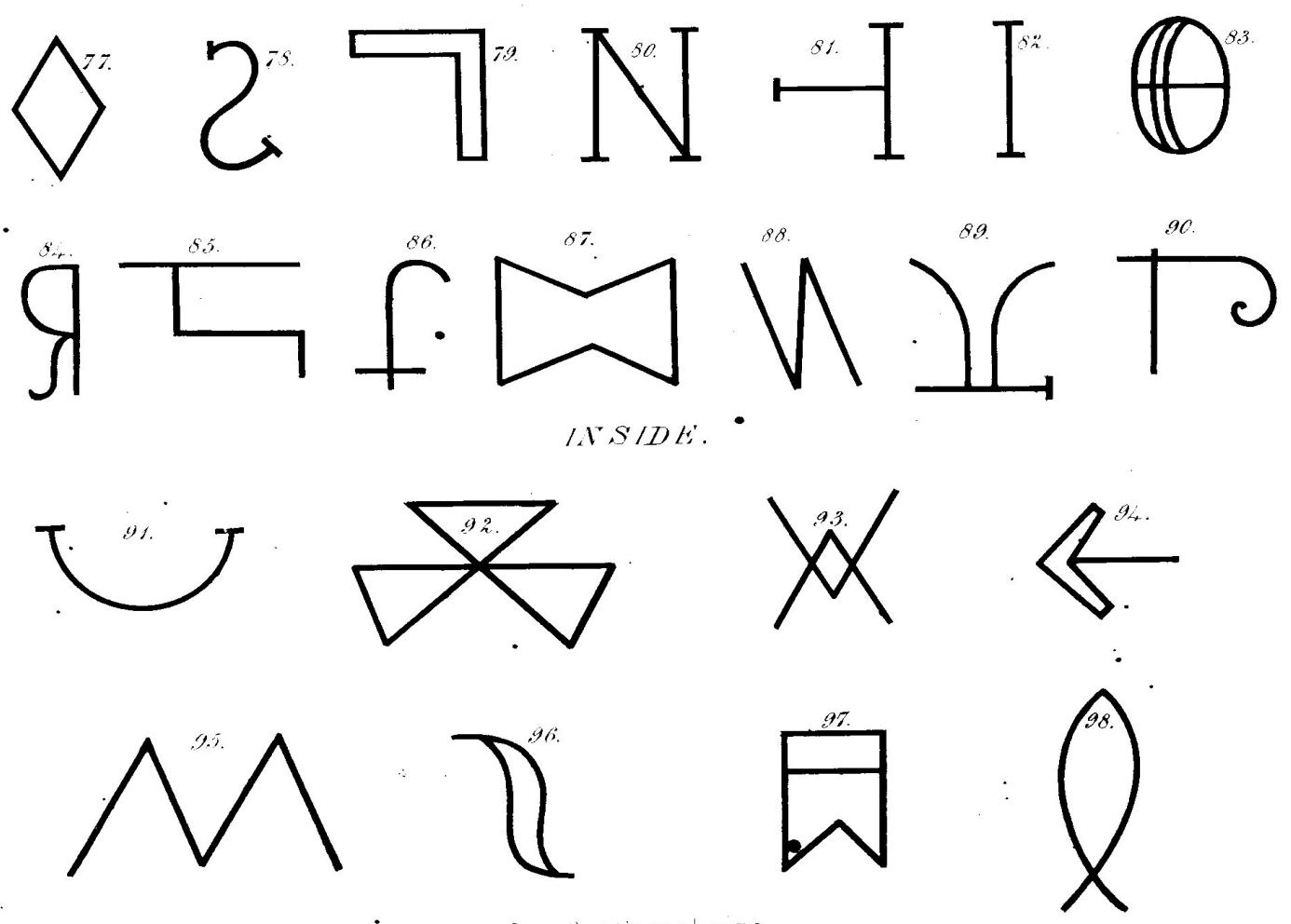
FトイメCH

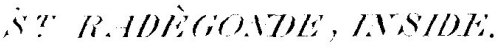

T
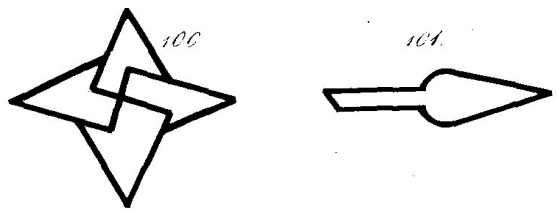

$\dot{\gamma}$
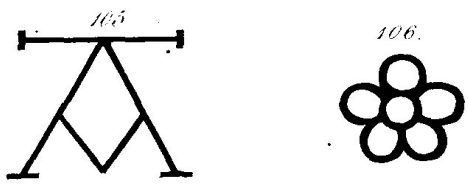
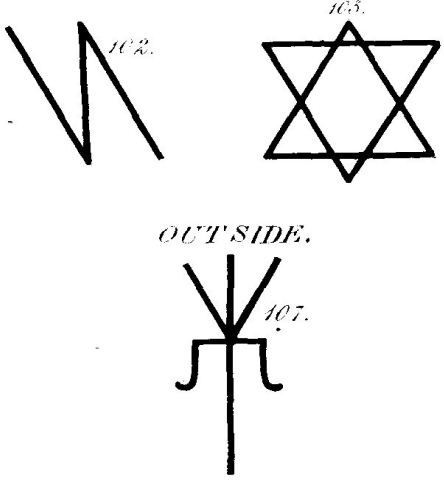

CHOMYE GITHEDRAL GERMAN Y. I.TFEROR.

$\overbrace{}^{*}$
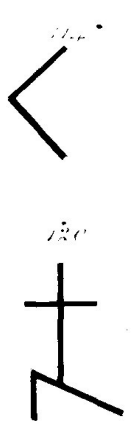

专
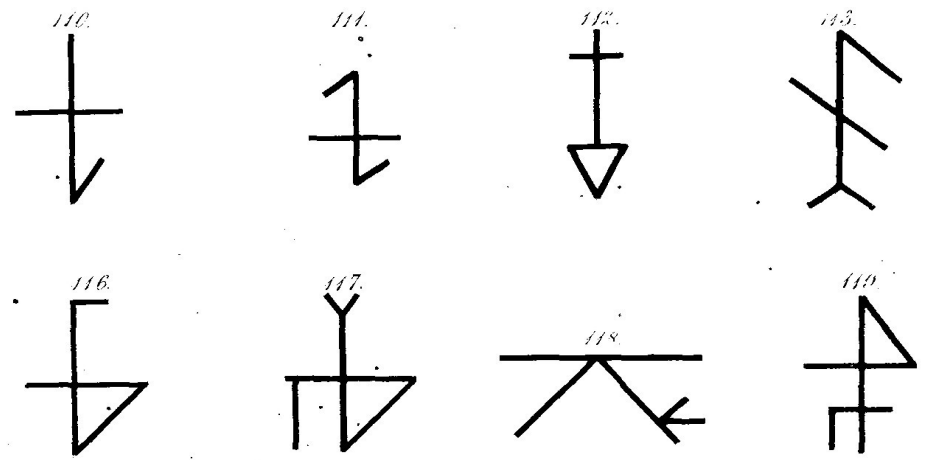
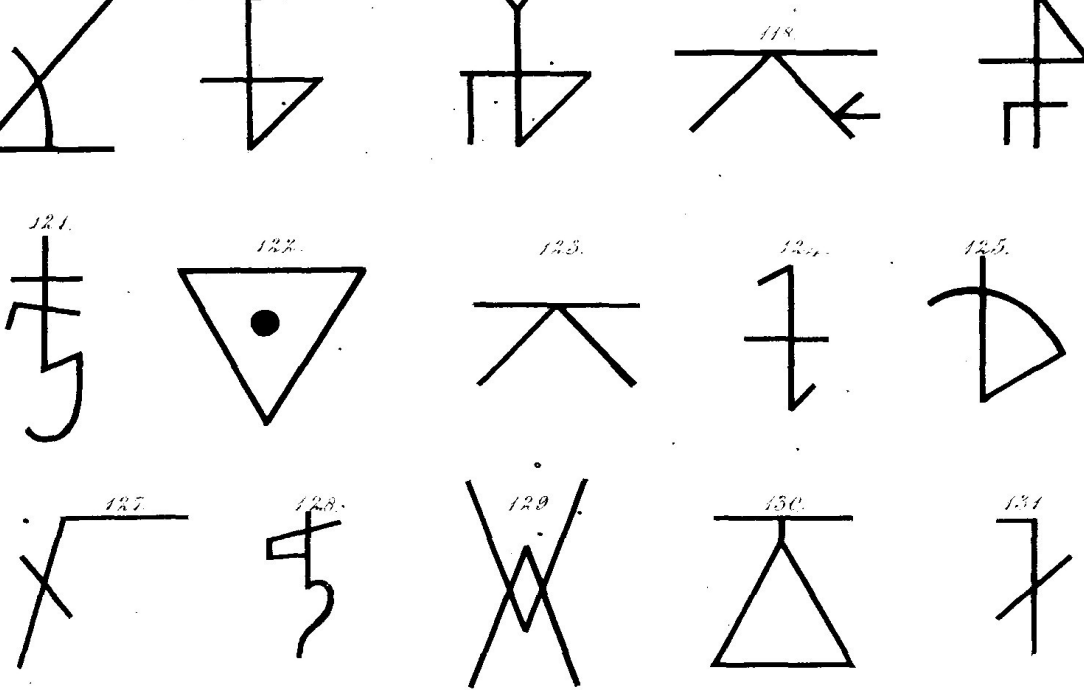

$.741 \% 9$ 
GE R MAN Y .

COLOGNE CATHEDRAL.

$$
\text { OUTSIUE. }
$$

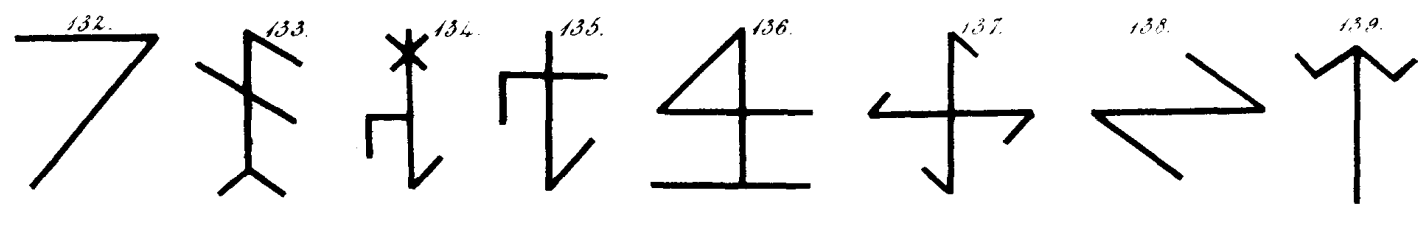

ST HVDREWS COLOGIE

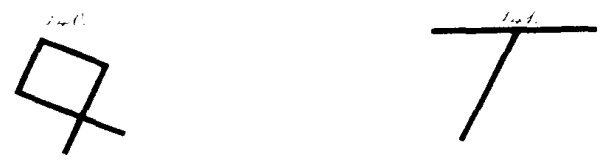

CHIRCH UF THE APQSTHES.
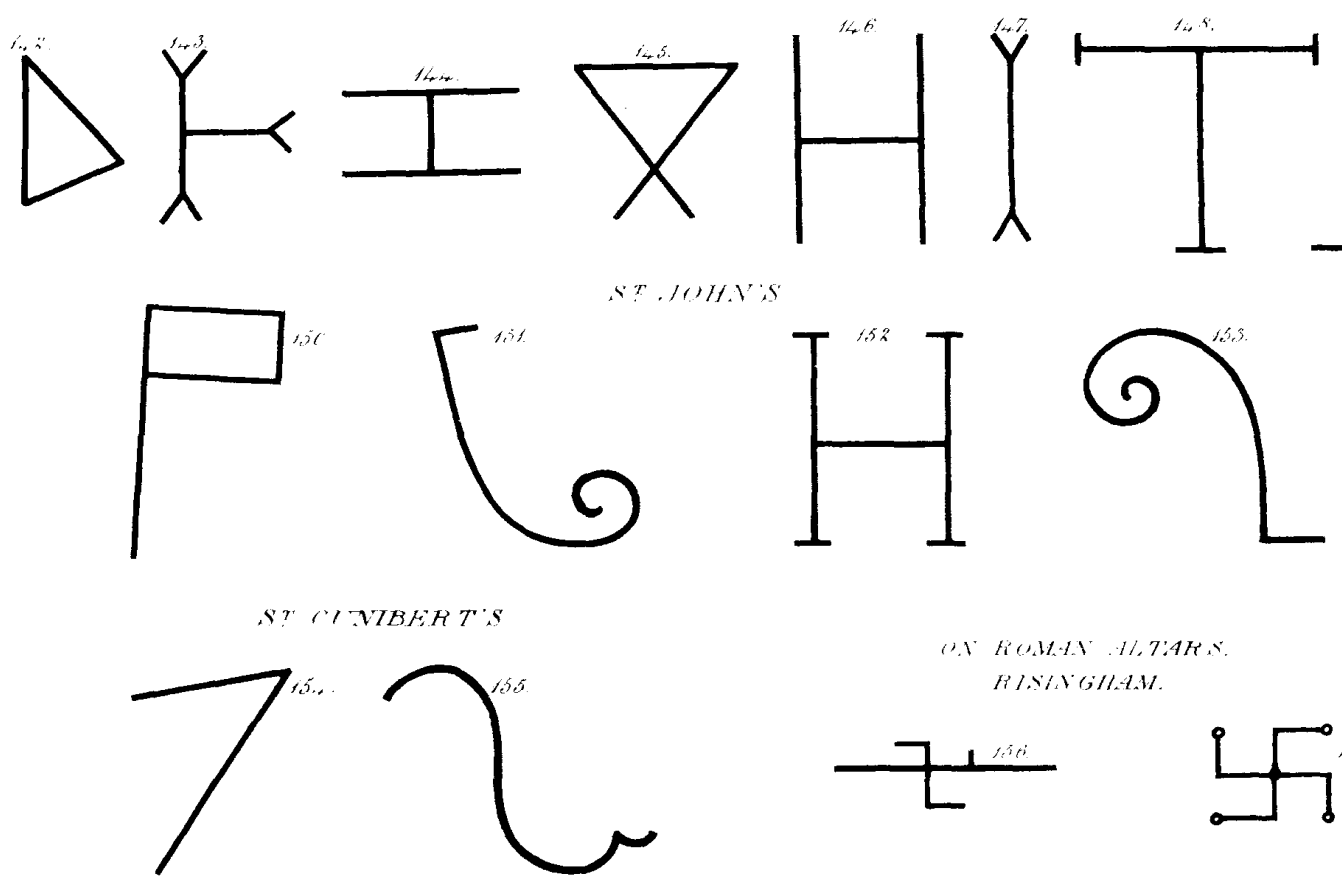

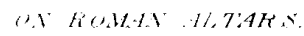
RISA 6 (I/LW.
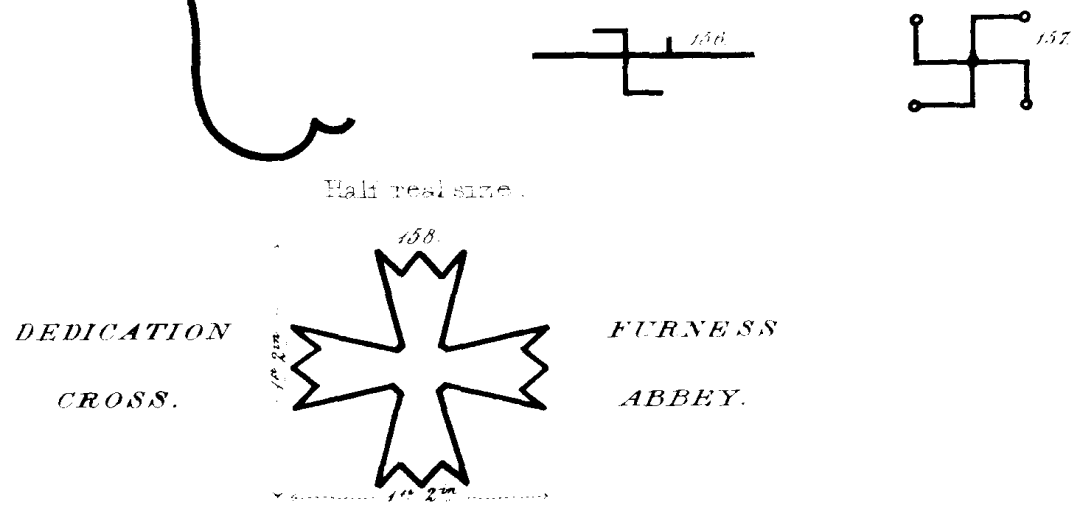

Mason's Marks. 